\title{
HUBUNGAN ANTARA STRES EMOSI DENGAN KUALITAS TIDUR LANSIA
}

\author{
Dahroni $^{1}$, Triana Arisdiani ${ }^{1}$, Yuni Puji Widiastuti ${ }^{1}$ \\ Program Studi Ilmu Keperawatan STIKES Kendal \\ dahronitohari@gmail.com,
}

\begin{abstract}
ABSTRAK
Lanjut usia adalah seseorang yang telah mencapai usia lebih dari 60 tahun dan megalami beberapa perubahan fungsi fisiologis yang akan berdampak pada kondisi fisik maupun psikologis diantara stres emosi. Tujuan : Penelitian ini bertujuan untuk mengetahui hubungan antara stres emosi dengan kualitas tidur pada lansia di Balai pelayanan sosial lansia. Metode : Penelitian ini merupakan study deskriptif korelasi dengan pendekatan cross sectional. Jumlah sampel sebanyak 74 orang. Hasil : ada hubungan yang signifikan antara stres emosi dengan kualitas tidur lansia dengan nilai $\mathrm{p}$ value $0,003(\mathrm{P}<0,05)$. Diskusi : Penelitian ini diharapkan dapat digunakan sebagai referensi untuk mengembangkan penelitian yang serupa, sehingga dapat meningkatkan kualitas hidup lanjut usia.
\end{abstract}

Kata Kunci: Stres emosi, kualitas tidur, lansia

\section{RELATIONSHIP BETWEEN EMOTIONAL STRESS AND SLEEP QUALITY}

\begin{abstract}
Advanced age is someone who has reached the age of more than 60 years and has several changes in physiological functions that will have an impact on the physical and psychological conditions between emotional stress. This research aims to determine the relationship between emotional stress and sleep quality in the elderly in the elderly social service center. This research is a descriptive correlation study with a cross sectional approach. The number of samples is 74 people. The result of the research was significant correlation between emotional stress and elderly sleep quality with a $p$ value of $0.003(P<0.05)$ The research is expected to be able to develop similar research so that it can improve the quality of life of elderly.
\end{abstract}

Keywords: Emotional stress, sleep quality, elderly

\section{PENDAHULUAN}

Lanjut usia adalah seseorang yang telah mencapai usia lebih dari 60 tahun. Pada pencapaian umur lanjut ini, seseorang akan megalami beberapa perubahan (Maryam, 2012). Perubahan yang terjadi diantaranya adalah penurunan. Perubahan fungsi fisiologis yang akan berdampak pada kondisi fisik dan psikologis mengakibatkan stres pada lansia (Nugroho, 2008).

Data WHO menunjukan pada tahun 2000 usia harapan hidup orang didunia adalah 66 tahun, pada tahun 2012 naik menjadi 70 tahun dan pada tahun 2013 menjadi 71 tahun (WHO, 2015). Jumlah lansia di Indonesia mencapai 20,24 juta jiwa, setara dengan 8,03 persen dari seluruh penduduk Indonesia tahun 2014. Jumlah lansia perempuan lebih besar daripada laki-laki, yaitu 10,77 juta lansia perempuan dibandingkan 9,47 juta lansia laki-laki. Adapun lansia yang tinggal di perdesaan sebanyak 10,87 juta jiwa, lebih banyak daripada lansia yang tinggal di perkotaan sebanyak 9,37 juta jiwa (Susenas, 2014).
Jumlah lansia yang banyak di Indonesia ini haruslah ditangani secara keseluruhan dengan memperhatikan kebutuhannya (Silvanasari, 2012). Kebutuhan fisiologis dasar manusia termasuk lansia yang harus dipenuhi adalah higiene, nutrisi, kenyamanan, oksigenasi, cairan elektrolit, eliminasi urin dan fekal serta kebutuhan tidur (Potter \& Perry, 2010).

Prevalensi gangguan tidur pada lansia tergolong tinggi yaitu sekitar 67\% (Seoud et al, 2014). Menurunnya kualitas tidur lansia akan berdampak buruk terhadap kesehatan, karena dapat menyebabkan kerentanan terhadap penyakit, stres konfusi, disorientasi, gangguan mood, kurang fresh, menurunnya kemampuan berkonsentrasi, kemampuan membuat keputusan (Potter\&Perry, 2010). Kualitas tidur adalah kepuasan seseorang terhadap tidur, sehingga seseorang tersebut tidak memperlihatkan perasaan lelah, mudah terangsang dan gelisah, lesu dan apatis, kehitaman di sekitar mata, kelopak mata bengkak, konjungtiva merah, mata perih, perhatian terpecah-pecah, sakit kepala dan sering menguap atau mengantuk (Hidayat, 
2006). Menurut Akersted Nilsson, dalam Kompier et al (2012), menyebutkan bahwa stres dan tidur mempunyai hubungan yang erat. Kualitas tidur yang buruk dapat dikaitkan dengan kesehatan mental seperti stres emosi pada lansia.

Stres emosi merupakan stres yang disebabkan karena gangguan situasi psikologis atau ketidakmampuan kondisi psikologis untuk menyesuaikan diri seperti hubungan interpersonal, sosial budaya atau faktor keagamaan. Individu sering menggunakan keadaan emosionalnya untuk mengevaluasi stres. Proses penilaian kognitif dapat mempengaruhi stres dan pengalaman emosional. Reaksi emosional terhadap stres yaitu rasa takut, fobia, kecemasan, depresi, perasaan sedih dan rasa marah (Suliswati, 2010). Penelitian yang dilakukan oleh Ramaita (2010) tentang hubungan tingkat stres dengan tingkat insomnia pada lansia di panti sosial tresna Werdha Sabai Nan Aluih Sicincin Padang Pariaman didapatkan hasil ada hubungan yang kuat antara tingkat stres dengan tingkat insomnia dengan nilai $\mathrm{p}$ value $0,000(\mathrm{p}<0,05)$.
Studi pendahuluan yang dilakukan peneliti pada tanggal 3 November 2016 wawancara dengan 8 lansia, 5 lansia diantaranya mengatakan tidak nyenyak tidur, sering terbangun dan tidak bisa melanjutkan tidur lagi, lansia tersebut juga menyampaikan sering tidak dapat mengontrol emosi. Dari masalah diatas maka peneliti tertarik untuk melakukan penelitian dengan judul hubungan antara status kesehatan fisik dan stres emosi dengan kualitas tidur pada lansia di Balai pelayanan sosial lansia Cepiring Kabupaten Kendal.

\section{METODE}

Jenis penelitian ini study deskriptif korelasi, pendekatan cross-sectional. Populasi sebanyak 80 orang, teknik sampling yang digunakan total sampel. Uji hasil data penelitian menggunakan $c h i$ square

\section{HASIL}

Hasil penelitian dapat dilihat pada tabel berikut.

Tabel 1

Karakteristik Responden $(\mathrm{n}=74)$

\begin{tabular}{lcc}
\hline Umur & $\mathrm{f}$ & $\%$ \\
\hline 55-64 tahun & 18 & 24,3 \\
$65-69$ tahun & 17 & 23,0 \\
$>70$ tahun & 39 & 52,7 \\
\hline Jenis kelamin & & \\
Laki-laki & 14 & 18,9 \\
Perempuan & 60 & 81,1 \\
\hline Riwayat penyakit & & \\
Hipertensi & 28 & 37,8 \\
Dimensia & 2 & 2,7 \\
Diabetes & 44 & 59,5 \\
\hline Riwayat minum obat & & \\
Pernah & 66 & 89,2 \\
Tidak pernah & 8 & 10,8 \\
\hline
\end{tabular}

Tabel 2

Distribusi Frekuensi Stres Emosi Lansia (n=74)

\begin{tabular}{lcc}
\hline Stres emosi & f & $\%$ \\
\hline Ringan & 44 & 59,5 \\
Sedang & 19 & 25,7 \\
Berat & 11 & 14,9 \\
\hline
\end{tabular}

Tabel 3

Distribusi Frekuensi Kualitas Tidur Lansia (n=74)

\begin{tabular}{lcc}
\hline Kualitas tidur & $\mathrm{f}$ & $\%$ \\
\hline Baik & 25 & 33,8 \\
Buruk & 49 & 66,2 \\
\hline
\end{tabular}




\section{PEMBAHASAN}

Hasil penelitian menunjukkan sebagian besar lansia berumur $>70$ tahun, berjenis kelamin perempuan, mempunyai riwayat DM dan pernah minum obat. Hasil penelitian terkait stress emosi lansia menunjukkan sebagian besar responden mengalami stres emosi ringan sebanyak 44 $(59,5 \%)$ responden. Stres emosi ringan yang terjadi pada lansia ditandai dengan sering merasa letih, merasa sedih, merasa asing, merasa susah tidur jika malam hari, merasa mudah terjaga dan sulit untuk tidur kembali. Stres emosi adalah stres yang disebabkan karena gangguan situasi psikologis atau ketidakmampuan kondisi psikologis untuk menyesuaikan diri seperti hubungan interpersonal, sosial budaya atau faktor keagamaan (Stuart dan Sundeen, 2007). Dampak negatif stres seperti tekanan darah tinggi, pusing, sedih, sulit berkonsentrasi, tidak bisa tidur seperti biasanya, terlampau sensitif, depresi, dan lainnya serta dalam kondisi tertentu, stres bisa menimbulkan berbagai keluhan (Suliswati, 2010).

Penelitian yang dilakukan oleh Manabung (2010) tentang faktor-faktor yang berhubungan dengan stres piskosoisal lansia di panti sosial tresna werdha Ilomata Kota Gorontalo didapatkan hasil lansia yang mengalami stres sedang sebanyak 94 $(87,5 \%)$. Hasil penelitian menunjukkan sebagian besar responden mengalami kualitas tidur buruk sebanyak 49 (66,2\%). Kualitas tidur buruk dikarenakan lansia susah untuk tidur, sering bangun di malam hari dan tidur tidak terlalu lama. Penelitian serupa yang dilakukan oleh Musfiati (2009) tentang hubungan tingkat stres dengan kualitas tidur lansia di PSTW unit budi luhur Yogyakarta didapatkan hasil sebagian besar lansia memiliki kualitas tidur buruk sebanyak 39 orang $(83 \%)$.

Kualitas tidur adalah ukuran dimana seseorang itu dapat kemudahan dalam memulai tidur dan untuk mempertahankan tidur, kualitas tidur seseorang dapat digambarkan dengan lama waktu tidur, dan keluhan - keluhan yang dirasakan saat tidur ataupun sehabis bangun tidur (Potter dan Perry, 2010). Sumedi, Wahyudi, dan Kuswati (2010), mengungkapkan bahwa kualitas tidur malam hari pada lansia mengalami penurunan menjadi sekitar 70-80\% dari usia dewasa. Faktor yang dapat mempengaruhi kualitas tidur buruk pada lansia dapat dikarenakan adanya gaya hidup yang buruk seperti kebiasaan tidak adanya pengaturan jam tidur dan adanya masalah dilingkungan tempat tinggal seperti masalah dengan lansia lainnya. Pernyataan tersebut didukung oleh pendapat Collins (2008), bahwa kualitas tidur seseorang dapat dipengaruhi oleh adanya gangguan kesehatan (penyakit), diet, olahraga, lingkungan, dan psikologisnya. Selain itu ada faktor-faktor lain yang dapat mempengaruhi kualitas tidur menurut Asmadi (2008) yaitu lingkungan, stres emosi atau psikologis, diet, gaya hidup dan obatobatan.

Hasil perhitungan menggunakan uji fishe'r exact test didapatkan nilai $\mathrm{p}$ value $0,001(\mathrm{P}<0,05)$. Hal tersebut menunjukkan ada hubungan antara stres emosi dengan kualitas tidur lansia di Balai pelayanan sosial lansia Cepiring Kabupaten Kendal.

Lansia yang mengalami stres emosi seperti merasa khawatir dengan masalah yang tidak jelas, merasa letih, bangun tidur badan terasa sakit, merasa capek, merasa jantung berdebar akan menyebabkan kualitas tidur yang menurun. Lansia yang mengalami stres akan mengalami kualitas tidur yang buruk, hal ini sesuai dengan pendapat Prayitno (2012) yang menyatakan depresi dan kecemasan seringkali mengganggu tidur. Seseorang yang dipenuhi dengan masalah mungkin tidak bisa rileks untuk bisa tidur. Kecemasan akan meningkatkan kadar norepinephrin dalam darah yang akan merangsang sistem saraf simpatetik. Perubahan ini menyebabkan berkurangnya tahap IV.

Penelitian yang berbeda dilakukan Musfiati (2015) tentang hubungan tingkat stres dengan kualitas tidur lansia di panti sosial tresna wredha unit budi luhur Yogyakarta didapatkan rata-rata responden tidak mengalami stres sebanyak 41 lansia $(87,2 \%)$ dan rata-rata memiliki kualitas tidur buruk sebanyak sebanyak 39 orang (83\%).

\section{SIMPULAN DAN SARAN Simpulan}

Sebagian besar responden berumur $>70$ tahun sebanyak $39(52,7 \%)$ berjenis kelamin perempuan sebanyak $60 \quad(81,1 \%)$ mempunyai riwayat penyakit diabetes sebanyak $44(59,5 \%)$ pernah minum obat sebanyak $66(89,2 \%)$, mengalami stres emosi ringan sebanyak $44 \quad(59,5 \%)$, mengalami kualitas tidur buruk sebanyak 49 $(66,2 \%)$. Ada hubungan signifikan antara stres emosi dengan kualitas tidur lansia.

\section{Saran}

Peneliti selanjutnya diharapkan dapat menggunakan hasil penelitian ini sebagai acuan penelitian selanjutnya dengan menggunakan metode kualitatif atau menggunakan variabel lain. 


\section{DAFTAR PUSTAKA}

Hidayat. A. (2006). Pengantar Kebutuhan Dasar Manusia: Aplikasi Konsep dan Proses Keperawatan. Jakarta. Salemba Medika.

Kompier et al. (2012). Tossing and turningInsomnia in Relation to occupational Stress, Rumination, Fatigue, and WellBeing. Scand J Work Environ Health 2012

Manabung (2010) faktor-faktor yang berhubungan dengan stres piskosoisal lansia di panti sosial tresna werdha Ilomata Kota Gorontalo

Maryam, Siti. (2012). Mengenal Usia Lanjut dan Perawatannya. Jakarta: Salemba Medika

Musfiati (2009) hubungan tingkat stres dengan kualitas tidur lansia di PSTW unit budi luhur Yogyakarta

Musfiati (2015) hubungan tingkat stres dengan kualitas tidur lansia di panti sosial tresna wredha unit budi luhur Yogyakarta

Nugroho. W. (2008). Keperawatan Gerontik dan Geriatrik. Jakarta:EGC.

Potter dan Perry, (2010). Buku Ajar Fundamental Keperawatan : Konsep,. Proses, dan
Praktik.Edisi 4.Volume 2.Alih Bahasa : Renata

Ramaita (2010). Hubungan Tingkat Stres dengan Tingkat Insomnia pada Lansia. Ners Jurnal Keperawatan

Silvanasari. (2012). Faktor-faktor yang Berhubungan dengan Kualitas Tidur yang Buruk pada Lansia di Desa Wonojati Kecamatan Jenggawah Kabupaten Jember. Skripsi. Jember; Universitas Jember

Stuart dan Sundeen. (2007). Buku Saku Keperawatan Jiwa Edisi 4. Jakarta : EGC

Sugiyono. (2015). Metode penelitian dan pendidikan. Pendekatan kuantitatif kualitatif. Bandung : Alfabeta

Suliswati. (2010). Konsep Dasar Keperawatan Jiwa. Jakarta : EGC

Susenas. (2014). Badan Pusat Statistik dalam Buletin Jendela Data dan Informasi.

WHO. (2015). Badan Pusat Statistik Republik Indonesia.

Yuliawati (2011) hubungan antara tingkat stres dengan tindak kekerasan pada Caregiver Lansia dengan Demensia . 